\title{
Linkages between Real Sector and Financial Sector in Nepal: A Vector Error Correction Model
}

\author{
Jeevan Baniya $\square$ \\ Shalik Ram Pokhrel(PhD) \\ Mukti Nath Dulal\#
}

\begin{abstract}
The financial development is considered as a pre-requisite condition for the overall economic development of the nation and rousing to economists. This paper investigates the short run and long run causality between monetary variables $\left(M_{1}, C P I, N F A, D C\right)$ and real sector variables (GDP, TE, TI) of Nepal using some of the econometric techniques like Johansen's co-integration analysis and the Vector Error Correction Model (VECM). The study employs the data from 1975 to 2014. The results of the investigation aver that there exists short run and long run causality between monetary and real sector variables. The impulse responses of exports and domestic credits show that these variables have positive impacts on the economic growth which is consistent with the theoretical frameworks. The impulse responses of GDP to domestic credit seemed insignificant in the short run and started to be significant in the long run gradually. On the contrary to this, the impulse response of GDP and domestic credit to export seemed negatively responsive. So, giving proper focus on the macroeconomic policies and strategies which reduces the nebulous situations of economy and promote the allocation of resources, production activities, and competitiveness to increase the domestic credits and exports will probably promote economic development of the nation.
\end{abstract}

Key Words: Linkages, Speed of Adjustment, VECM, JEL Classification: C52, E51

\#Financial Manager Pancha Buddha sub-remittance Company, Melamchi, Sindhupalchok, Nepal. Assistant Director, Nepal Rastra Bank, Kathmandu, Nepal Director, Pancha Buddha sub-remittance 口Company, Melamchi, Sindhupalchok, Nepal.

$5^{\text {th }}$ International Conference on New Ideas in Management, Economics and Accounting 


\section{REFERENCES}

Abubakar,A. \& Gani,I.M. 2013. "Impact of Banking Sector Development on Economic Growth: Another Look at Evidence from on Nigeria.” Journal of Business Management and Social Science Research (JBM \& SSR) ISSN No. 2319-5614 Volume 2, No.4, April 2013.

Akinbobola,T.O.2012.“The Dynamics of Money Supply, Exchange Rate and Inflation in Nigeria.”Journal of Applied Finance and Banking, Vol.2. No.4,2012.117-

141.ISSN.1792-6580 (Print Version).1792-6599 (Online Version). Scinpress Ltd 2012.

Gunes.S.(na). "Functional Income Distribution in Turkey: A Cointegration and VECM Analysis." Journal of Economic and Social Research 9(2),23-26.

Kizito, E.U.2013. " The Link Between Monety Market and Economic Growth in Nigeria:

Vector Error Correction Approach.” World Academy of Science, Engineering and Technology, International Journal of Social, Management, Economics and Business Engineering, Vol.7, No.12.2013.

Kularatne,C.na."An examination of the impact of the financial deepening on longrun economic growth: An application of a VECM structure to a middleincome country context." University of the Witwatersrand.

Mello,L.D.Piseu, M.2009. "The Bank Lending Channel of Monetary

Transmission of Brazil: A VECM approach." Economics Department Working Paper No.711.10- July 2009. Available at: www.oecd.org/eco/working_papers.

Peetz,D. \&Generith, H.2011. "The Financial Sector and the Real Economy."Real World Economics Review issue no.57. Institute for Applied Risk Management,Germany.

Rehman,A. \& Ceema,A.R.2013. "Financial Development and Real Sector Growth in

Pakistan.'Interdeciplinary Journal of Contemporary Research in Business.Vol.5, No.1.May.2013.

Samsi, S.M.(et.all) 2012."Linkages Between the Real Sector and the Financial

Sector: The Case of Malaysia." Asian Academy of Management Journal of Accounting and Finance, AAMJAF, Vol.8 (Supp.1),93-113,2012.

Taha, R.et all.2009. "Financial Development and Economic Growth in Malaysia : Cointegration and Co-feature Analysis. Monasa University, Deparment of Economics.Issn 1441-5429. Discussion Paper 31/09.

Tjipe,T.et.al.2004. “NamibiaMacroeconometric Model (NAMEX)” Macroeconomic Modeling and Forecasting, Research Department, Bank of Namibia.

Wongpiyabovorn,O.2014. “Impacts of Financial Development on Economic Growth: Evidence from Thailand, Malaysia, and The Philippines." Thammasat University, Thailand 